\title{
Designing A New Suitable Support System for Deep Virgin Coal Mining Blocks of Godavari Valley Coalfield
}

Vikram Shankar ( $\nabla$ ajayvaish007@gmail.com )

National Institute of Rock Mechanics Champion Reefs https://orcid.org/0000-0001-7145-7487

Dheeraj Kumar

Indian School of Mines: Indian Institute of Technology

Duvvuri Satya Subrahmanyam

National Institute of Rock Mechanics Champion Reefs

Case study

Keywords: Underground coal mining, Bord and pillar mining, Finite element method, High horizontal Stress, Rock mass classification

Posted Date: February 8th, 2021

DOI: https://doi.org/10.21203/rs.3.rs-190788/v1

License: () (i) This work is licensed under a Creative Commons Attribution 4.0 International License. Read Full License 


\section{Abstract}

Importance of support system in mine design gained pace after modern way of approach took birth through many variants. A suitable support system is designed for deep virgin coal mining blocks of Godavari valley coalfield in India. This is achieved by measuring stress state by sophisticated method followed by geotechnical hazard mapping for identifying potential roof instability, predict hazards in advance and integrating the above parameters for analyze effects on stress due to different mining geometries by using numerical modelling technique. The three-dimensional numerical analysis study pours much light on effects causing instability than the 2D program. The results show that the stresses at an angle to the Level galleries are adverse. The level gallery/dip-raise may be oriented at 200 to 400 to reduce roof problems.

\section{Introduction}

Mining below ground is the main factor for stress redistribution and large-scale movement of the roof strata. Therefore, the study of Stress is critically important to develop techniques for efficient coal mining [9]. Underground coal mining experience dynamic stress changes due to the decrease in confining Stress, which will increase stratum deformation induced by in-situ stresses in the rock mass [14].

In underground excavations, especially in coal mining, horizontal Stress plays a vital role in the stability of the mine workings. It is essential to understand the influence of stresses on drive direction and the roadway conditions. High horizontal Stress is one of the crucial factors responsible for the overall stability of coal mine roadways.

Measurements of horizontal stresses at mining sites around the world show that the horizontal to vertical stress ratio (K) tends to be high at shallow depth and that it decreases at depth [4]. It has been proved beyond doubt that the high horizontal stress $(K>1)$ values have a profound influence on the stability of mine roadways where the roof is laminated.

Numerical studies help to analyze the mere cause [5]. Basalt flow and faults has also been reported from Pench area (Western Coalfield Ltd), and it has been found that high horizontal Stress affects the stability of development galleries at Thesgora mines [13].

Manohara Rao and Sharma [7] reported in their studies that after reorientation of dip galleries closer to the mapped minimum principal horizontal stress direction, no bed dilation was observed in the roof strata of the dip galleries, with improvement in working conditions.

\section{Approach For Devising New Support System}

The knowledge of in-situ stresses can be utilized for explaining severe roof stability problems encountered in some Indian coal mines. High horizontal stress values have a profound influence on the overall stability of coal mine roadways where the roof is generally laminated. Early research work and field observations indicated that many roof failures, especially shear failure and floor heave problems in coal mines are associated with high horizontal stresses.

It is clear that the maximum horizontal stress which is responsible for roof failure can change its direction even up to $70^{\circ}$. This stress perturbation gives the clue that why in the same stretch of level galleries/dip rises having similar rock type, strike of the bed and joint pattern does not have a continuous roof problem.

A thorough investigation proves the Causes of failure and Means to check the failure. This can be assessed under the following objectives.

i. Measurement of principal stresses by hydraulic fracturing method and evaluation of principal stress magnitudes and directions using latest software.

ii. Geotechnical mapping for identifying potential roof instability, to make site specific recommendations and to predict roof hazards in advance.

iii. Correlating the stress tensors with geological structures of the study area with help of numerical modelling study.

iv. Investigation of stress redistribution due to mining geometry using simple numerical modelling to understand mechanism which cause instability in roof.

v. Investigation through alternate mine geometries that might reduce ground control problems and formulation of site-specific support system.

\section{Overview Of Study Area}

The current study area Mandamarri coal belt belongs to Pranahita-Godavari valley basin. It mostly follows the course of Pranahita and Godavari rivers. Based on the geological and structural setup and the nature of the lithic fill, it is termed as Godavari Gondwana Graben, this divided broadly into four sub-basins: (i) Godavari sub-basin, (ii) Kothagudem sub-basin, (iii) Chintalapudi sub-basin and (iv) Krishna-Godavari coastal sub-basin in Telangana. Further, they are divided into 11 coal belts (Fig. 1). Recent overcoring measurements across a graben fault system in a coal mine in Utah showed the occurrence of abnormally high horizontal and vertical stresses [1, 3]. Longwall mining operations across to graben were accomplished with high amounts of floor heave in the tail gate. The abnormal stresses associated with local geological structures are probably widespread and can cover large mining areas. They can impact mine stability and increase operational costs significantly. Hence the knowledge of in-situ stresses is indispensable for safety and suitable support system for coal mines in general and in specific owing to the precise structural/ geological setup, like the experience cited above.

\section{In-situ Stress Measurements In Deep Virgin Coal Mining Blocks Of Godavari Valley Coalfield}

Singareni Collieries Company Ltd is proposing some new mining blocks in the Godavari valley coalfield with status document with roof hazard zonation maps vis-à vis stress field, for safe and economical mine design. Hence, National Institute of Rock Mechanics, conducted stress measurements by hydraulic 
fracturing method in the newly proposed mining blocks at Mandamarri areas of Singareni collieries at deeper levels from the surface up to $600 \mathrm{~m}$ depth to find out the existing stress regime.

Hydraulic fracturing is the only rock stress determination technique that has been successfully applied to deep drill holes. This test gives the magnitude and orientation of principal stresses (Table 1).

\section{Geotechnical Mapping}

Geotechnical mapping is prepared in a comprehensive way to anticipate well in advance in different geotechnical and geo-mechanical parameters that are likely to be negotiated during development of galleries or panels. This gives ability to assess the degree of potential hazard. This is used to understand the strata behavior.

The various parameters that may impact the stability of roof are presented in the form of roof hazard maps. The different parameters considered for preparation of roof hazard map are accessed through boreholes drilled in Mandamarri coal block. The cores are tested at immediate roof of coal seam and accessed for different parameters such as tensile strength, compressive strength, caving index, shear strength \& modulus of elasticity of rock mass. This are mapped in database for assessing essential information tracing areas of instability (Figs. 2 to 4 ).

\section{Model Description And Simulation}

The model is $500 \mathrm{~m}$ wide, $500 \mathrm{~m}$ long, and $203 \mathrm{~m}$ high and the mining block size is $244.8 \mathrm{~m}$ wide and $244.8 \mathrm{~m}$ long. The panel is further developed through driving galleries (mine roadways) parallel and across the strike of the coal seam forming pillars of size $48.8 \mathrm{~m}$ wide and $48.8 \mathrm{~m}$ long. The size of the drivage is $4.8 \mathrm{~m}$ wide and $3 \mathrm{~m}$ high (Fig. 5) [10-12]. The rock mechanical parameters utilized in simulation is given in Table 2.

\section{Redistribution Of Major Principal Stress (Sh)}

The results are shown in Figs. 6, 7 \& 8. The maximum stress at the roof is observed when Max. Horizontal Principal Stress is $85^{0}$ to orientation of level gallery/dip raises. The minimum stress at the roof is observed when Max. Horizontal Principal Stress is parallel to orientation of level gallery/dip raises:

\section{Roof Convergence}

The results are shown in Figs. 9, $10 \& 11$. The maximum deformation at the roof is observed when Max. Horizontal Principal Stress is $85^{0}$ to orientation of level gallery/dip raises. The minimum deformation at the roof is observed when Max. Horizontal Principal Stress is parallel to orientation of level gallery/dip raises:

\section{Redistribution Of Shear Stresses (Ss)}

The results are shown in Figs. 12, 13 \& 14. The maximum shear stress at the roof is observed when Max. Horizontal Principal Stress is $85^{0}$ to orientation of level gallery/dip raises. The minimum shear stress at the roof is observed when Max. Horizontal Principal Stress is parallel to orientation of level gallery/dip raises:

\section{Shear Displacements (Sd)}

The results are shown in figures $15,16 \& 17$. The maximum shear deformations at the roof are observed when Max. Horizontal Principal Stress is $85^{0}$ to orientation of level gallery/dip raises. The minimum shear stress shear deformations and total deformation at the roof is observed when Max. Horizontal Principal Stress is parallel to orientation of level gallery/dip raises:

As the block is yet to be developed, it is understood from the above observations that the level gallery/dip-raise may be oriented at $20^{\circ}$ to $40^{\circ}$ to reduce roof problems (Table 3).

\section{Design Of Suitable Support System}

A systematic and scientific way of support system is developed by numerical modeling (Figure 18). Kushwaha et al. [6], in his study, developed empirical relationships (1), (2) \& (3) for determining load intensity \& support design for Indian coal mine block. The same has been applied in this study. The framework includes rock mechanical properties of the strata, local geological conditions \& mining methodology. From this, Weighted RMR for the strata is evaluated (Table 4).

The equation for estimating the load intensity $\mathrm{P}_{\mathrm{r}}$ in development roadways:

$P_{r}$ in $t / m^{2}=\gamma B F\left[1.7-0.037 R M R+0.0002\left(R M R^{2}\right)\right]$

Where $\mathrm{Y}$ is the unit weight of the rock, $\mathrm{t} / \mathrm{m}^{3}, \mathrm{~B}$ is the roadway width, $\mathrm{m}$ and $\mathrm{F}$ is the factor of safety, and RMR is the average rock mass rating of the immediate roof after adjustment. A factor of safety of 1.5 is generally considered enough.

The equation for estimating the applied support load (ASL) is given as: 
Where $\mathrm{n}$ is the number of bolts in a row, $\mathrm{A}$ is the Anchorage strength of each bolt (tonnes), $\mathrm{W}$ is the width of the roadway meters, and a is the spacing between two consecutive rows in meters.

The safety factor (SF) for supports is estimated by the following relation:

$\mathrm{SF}=\mathrm{ASL} / \mathrm{P}_{\mathrm{r}}$

From the above relations, the estimated load intensity is $4.042 \mathrm{t} / \mathrm{m}^{2}$. By considering the anchorage strength of bolt of 8 tonnes, the applied support load shall be of $8.333 \mathrm{t} / \mathrm{m}^{2}$. Hence factor of safety shall fall under the safe category of 2.061 , which can be considered for support design in coal mine block.

The support design can go as per the recommendations given below in Table 5.

The same has been assigned to numerical simulation for studying the effects on major horizontal principal Stress, roof displacement, shear stress, and shear displacement on different mine geometries (Figure 19). These parameters are essential in studying the redistribution of Stress for designing mine openings.

\section{Conclusion}

Support design can only be assessed in conjunction with rock structure. The strength of the rock depends on primarily the in-situ and mining induced stresses. In any design, analysis begins with evaluation of two fundamentals: (a) The strength of the structure and (b) The forces by means of load on it [8].

Rock structures are unique in that the strength of one essential component, the rock itself, can seldom be determined accurately. Similarly, the ground stresses are rarely well understood. A novel technique to compensate for these deficiencies has to be developed. This study helps to frame guidelines for suitable support design for the underground coal mine workings.

In Indian coal mines, CMRI Geo-mechanical classification (CMRI-RMR) and NGI Rock mass Quality classification (NGI-Q) System are mostly used for formulating support design in rock engineering. CMRI-RMR is used during development stage of mine and NGI-Q at final extraction (depillaring) [2]. Geotechnical investigations of the roof rocks play an important role in the selection of different parameters used in rock mass classifications.

For better understanding of the stability, analysis of the stress distribution is conducted through numerical modelling for different mine geometries. There are certain input parameters for the study has to be assessed in field conditions l.e., in-situ measurements with geotechnical studies for the mining blocks. This will be a solution for design of support system.

\section{Declarations}

\section{Acknowledgments}

The authors are thankful to the management and ground staffs at the test sites of Singareni Collieries Company Ltd (Telangana) for their co-ordination and concentrated efforts. The authors are also thankful to the Director of NIRM, for providing valuable suggestions and permission to publish this paper.

\section{References}

[1] Agapito JFT, Gilbride LJ. Horizontal Stresses as Indicators of Roof Stability, SME Annual Meeting Feb.25-27, Phoenix, Arizona, Preprint, 2002. p. 02-056.

[2] Ajoy K Singh, Sinha A, Paul A, Saikia K. Geotechnical investigations for support design in depillaring panels in Indian coal mines, Journal of Scientific \& Industrial Research, Vol. 64, 2005, pp. 358-363.

[3] Gale WJ, Fabjanczyk MW. Strata Control Utilizing Rock Reinforcement Techniques in Australian Coal Mines, Symposium on Roof Bolting, Poland, 1991.

[4] Hoek E, Brown ET. Underground Excavations in Rock, Institution of Mining and Metallurgy, 1980. p. 100, $183-241$.

[5] Kong P, Jiang L, Jiang J, Wu Y, Chen L, Ning J, Numerical Analysis of Roadway Rock-Burst Hazard under Superposed Dynamic and Static Loads. Energies, 12, 2019. p. 3761.

[6] Kushwaha A, Singh SK, Tewari S, Sinha A. International Journal of Rock Mechanics \& Mining Sciences, 47, 2010. p.1063-1078.

[7] Manohar Rao, Sharma DN. Stress Orientation in the Godavari Gondwana Graben, India, Journal of Rock Mechanics \& Tunnelling Technology, $20(2), 2014$. p. 109-119.

[8] Mark, Christopher \& Barczak, Thomas. FUNDAMENTALS OF COAL MINE ROOF SUPPORT. Proceedings of the NIOSH Open Industry Briefing. 2000.

[9] Qian M, Xu J. Study on the "O shape" circle distribution characteristics of mining induced fractures in the overlying strata. Journal of China Coal Society, 23(5),1998. p. 466-9.

[10] Rocscience. 3D Meshing Customization Developers Tips. 8 Rocscience Inc. 2013. 
[11] Rocscience. Personal Communication, 2014a.

[12] Rocscience. Phase2 Theory - Convergence Criteria. 4. 2014b.

[13] Sanyal K, Bahadur AN. A Geotechnical Study for Roof Control of Thesgora Mine, Pench Area, Western Coal Fields Ltd., National Conference on Ground Control in Mining, BHU. 1996.

[14] Shengwei Li, Mingzhong Gao, Xiaojun Yang, Ru Zhang, Li Ren, Zhaopeng Zhang, Guo Li, Zetian Zhang, Jing Xie. Numerical simulation of spatial distributions of mining-induced stress and fracture fields for three coal mining layouts. Journal of Rock Mechanics and Geotechnical Engineering. 10: (2018). p. 907-913. https://doi.org/10.1016/j.jrmge.2018.02.008.

\section{Table}

Table 1 Principal stress tensors as evaluated for the study area

\begin{tabular}{|l|l|}
\hline Principal stresses & Results \\
\hline Vertical Stress $\left(\mathrm{S}_{\mathrm{V}}\right)$ in MPa (Calculated with an overburden of $517.55 \mathrm{~m}$ and density of rock $=2400 \mathrm{~kg} / \mathrm{m}^{3}$ & 12.17 \\
\hline $\mathrm{S}_{\mathrm{H}}$ & $12.44 \pm 0.16$ \\
\hline $\mathrm{S}_{\mathrm{h}}$ & $6.22+0.08$ \\
\hline $\mathrm{S}_{\mathrm{H}}$ orientation & $40^{0}$ \\
\hline $\mathrm{K}=\mathrm{S}_{\mathrm{H}} / \mathrm{S}_{\mathrm{V}}$ & 1.22 \\
\hline
\end{tabular}

Table 2 Different input parameters considered for the simulation

\begin{tabular}{|lll|}
\hline Properties & Coal & Non-Coal \\
\hline Density $\left(\mathrm{Kg} / \mathrm{m}^{3}\right)$ & 1510 & 2290 \\
\hline Bulk Modulus K $(\mathrm{GPa})$ & 2.12 & 9.66 \\
\hline Shear Modulus G $(\mathrm{GPa})$ & 0.99 & 4.46 \\
\hline Cohesion C $(\mathrm{MPa})$ & 2.0 & 2.30 \\
\hline The angle of Friction $\varphi$ (Degree) & 20 & 34 \\
\hline Tensile strength $(\mathrm{MPa})$ & 1.0 & 0.25 \\
\hline
\end{tabular}

Table 3 Observations at the level gallery /dip-raise

\begin{tabular}{|lllll|}
\hline Case & $\mathrm{S}_{\mathrm{H}}$ & Deformation & $\mathrm{S}_{\mathrm{S}}$ & $\mathrm{S}_{\mathrm{d}}$ \\
\hline i) $\left(\mathrm{S}_{\mathrm{H}}\right)$ parallel to level gallery & 18.00 & 12.52 & 6.00 & 1.75 \\
\hline ii) $\left(\mathrm{S}_{\mathrm{H}}\right)$ is $40^{0}$ to level gallery & 18.00 & 12.53 & 6.50 & 1.75 \\
\hline iii) $\left(\mathrm{S}_{\mathrm{H}}\right)$ is perpendicular $\left(85^{\circ}\right)$ & 20.00 & 12.88 & 7.50 & 2.00 \\
\hline
\end{tabular}

Table 4 Weighted RMR evaluated for the strata

\begin{tabular}{|c|c|c|c|c|c|c|c|c|c|c|c|c|c|c|c|}
\hline \multirow[t]{2}{*}{ Layer } & \multirow[t]{2}{*}{ Rock type } & \multirow[t]{2}{*}{$\begin{array}{l}\text { Density } \\
\text { (t/cum) }\end{array}$} & \multicolumn{2}{|c|}{$\begin{array}{l}\text { Layer } \\
\text { thickness }\end{array}$} & \multicolumn{2}{|c|}{$\begin{array}{l}\text { Structural } \\
\text { features }\end{array}$} & \multicolumn{2}{|c|}{ Weatherability\% } & \multicolumn{2}{|c|}{ Strength (MPa) } & \multicolumn{2}{|c|}{$\mathrm{GW}(\mathrm{ml} / \mathrm{min})$} & \multirow[t]{2}{*}{$\begin{array}{l}\text { RMR } \\
\text { Value }\end{array}$} & \multicolumn{2}{|c|}{ Classification } \\
\hline & & & $\mathrm{cm}$ & Rating & Index & Rating & Value & Rating & Value & Rating & Value & Rating & & Class & Descriptior \\
\hline 1 & MGSST & 2.18 & 30 & 24 & \multirow[t]{4}{*}{5} & \multirow[t]{4}{*}{20} & 82 & 8 & 0.85 & 0 & \multirow[t]{4}{*}{10} & \multirow[t]{4}{*}{8} & 49 & \multirow[t]{4}{*}{ III } & \multirow[t]{4}{*}{ FAIR } \\
\hline 2 & MTCGSST & 2.2 & 52 & 27 & & & 91 & 11 & 11.9 & 4 & & & 57 & & \\
\hline 3 & FTMGSST & 2.23 & 49 & 27 & & & 88 & 10 & 13.3 & 4 & & & 56 & & \\
\hline 4 & CTVCGSST & 2.2 & 69 & 30 & & & 89 & 10 & 12.1 & 4 & & & 58 & & \\
\hline
\end{tabular}

Table 5 Support recommendation for coal mine block 


\section{Recommended Support Details}

Roof Bolts 1.8 M Length $22 \mathrm{~mm}$ diameter

Spacing 1.0 $\mathrm{M}$ across and along with galleries

Bolt density $7750 \mathrm{~kg} / \mathrm{m} 3$, Young's modulus $2 \mathrm{e} 11 \mathrm{~N} / \mathrm{m}$, Tensile strength $1.65 \mathrm{e} 5 \mathrm{~N} / \mathrm{m}$.

\section{Figures}

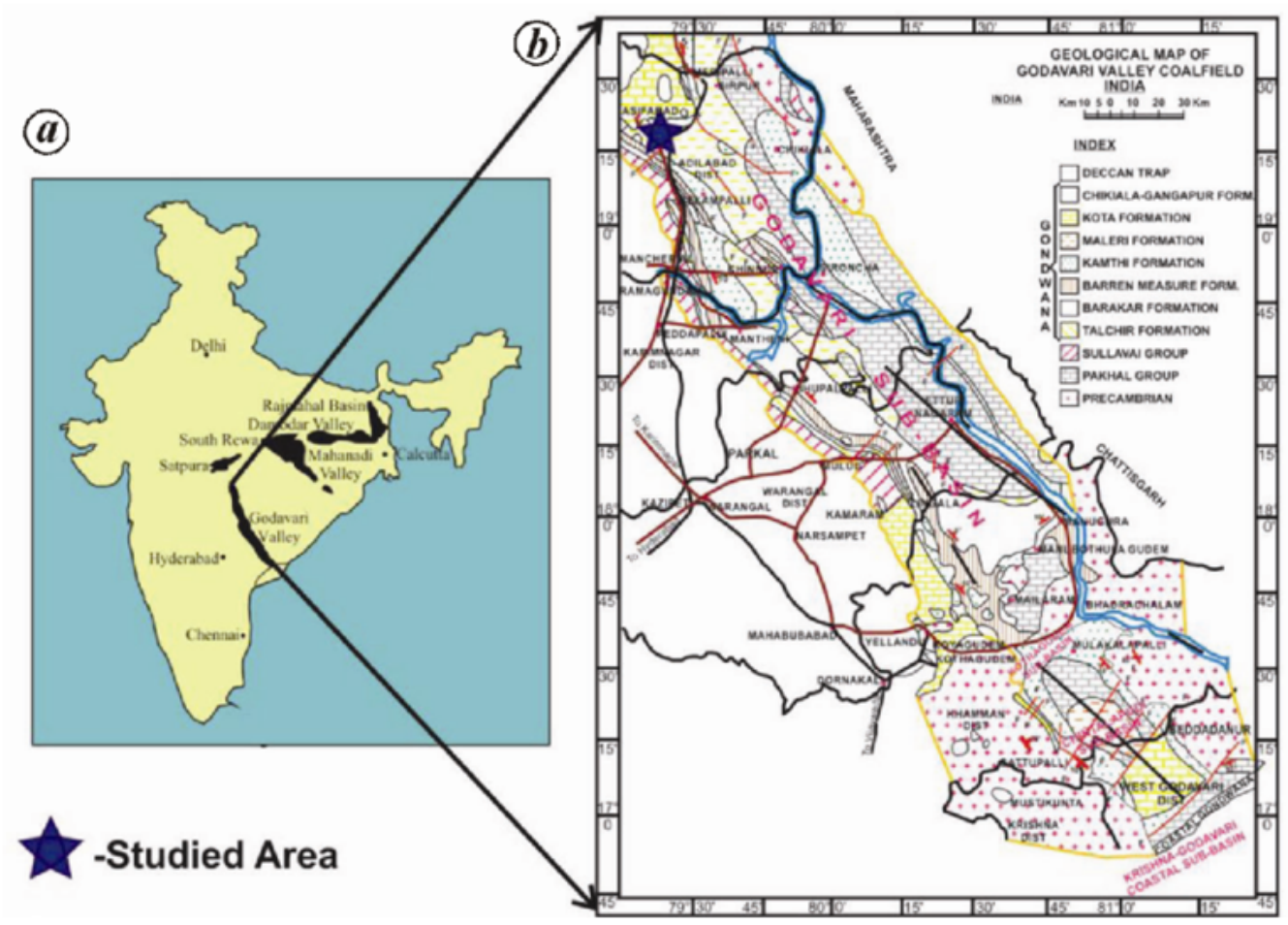

Figure 1

Geological Map of Godavari Valley Coalfield (Courtesy: https://scclmines.com/scclnew/company_about-us_godavari-valley-map.asp)

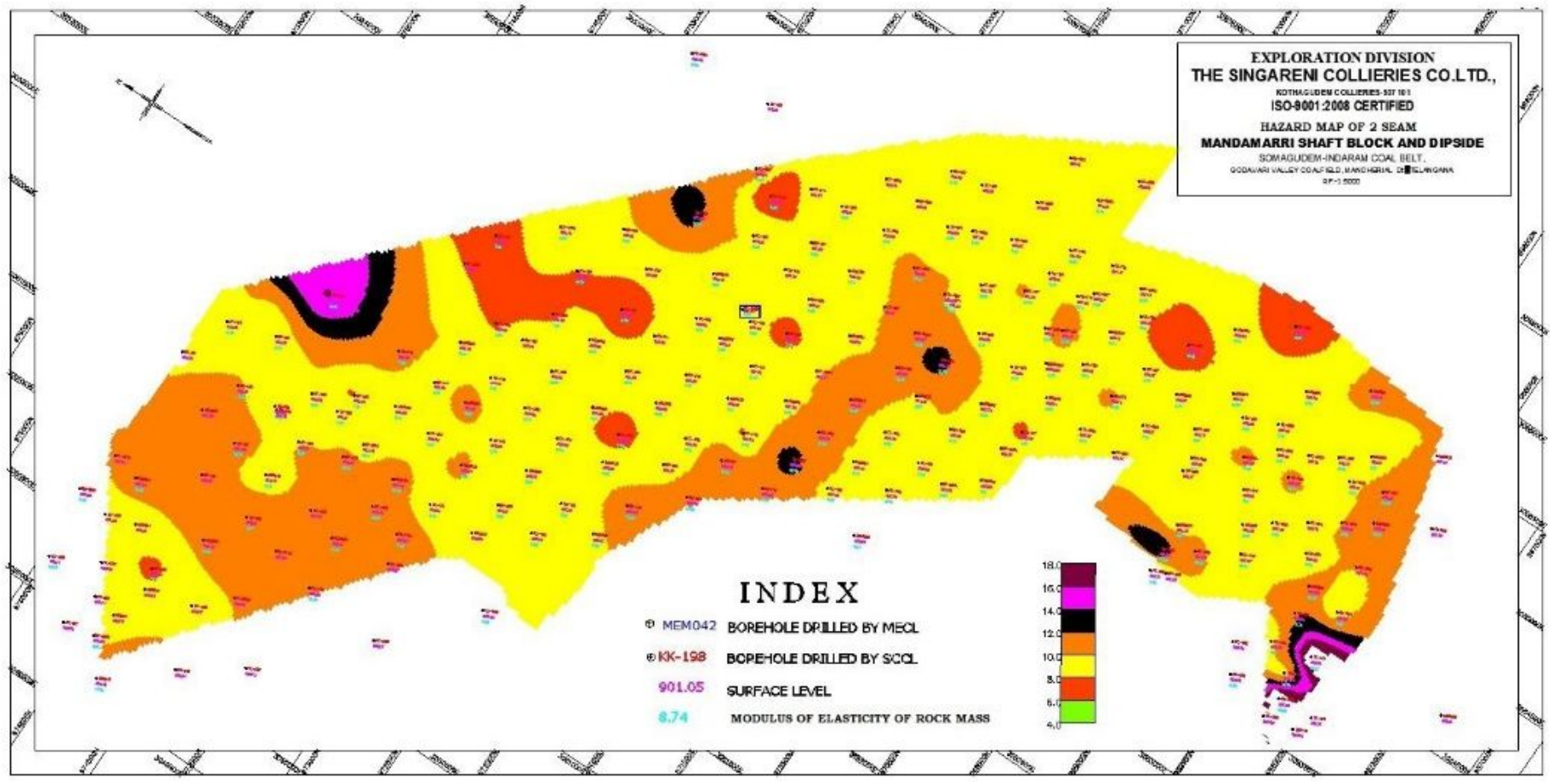

Figure 3 
Hazard map of 2 seam (Modulus of elasticity)

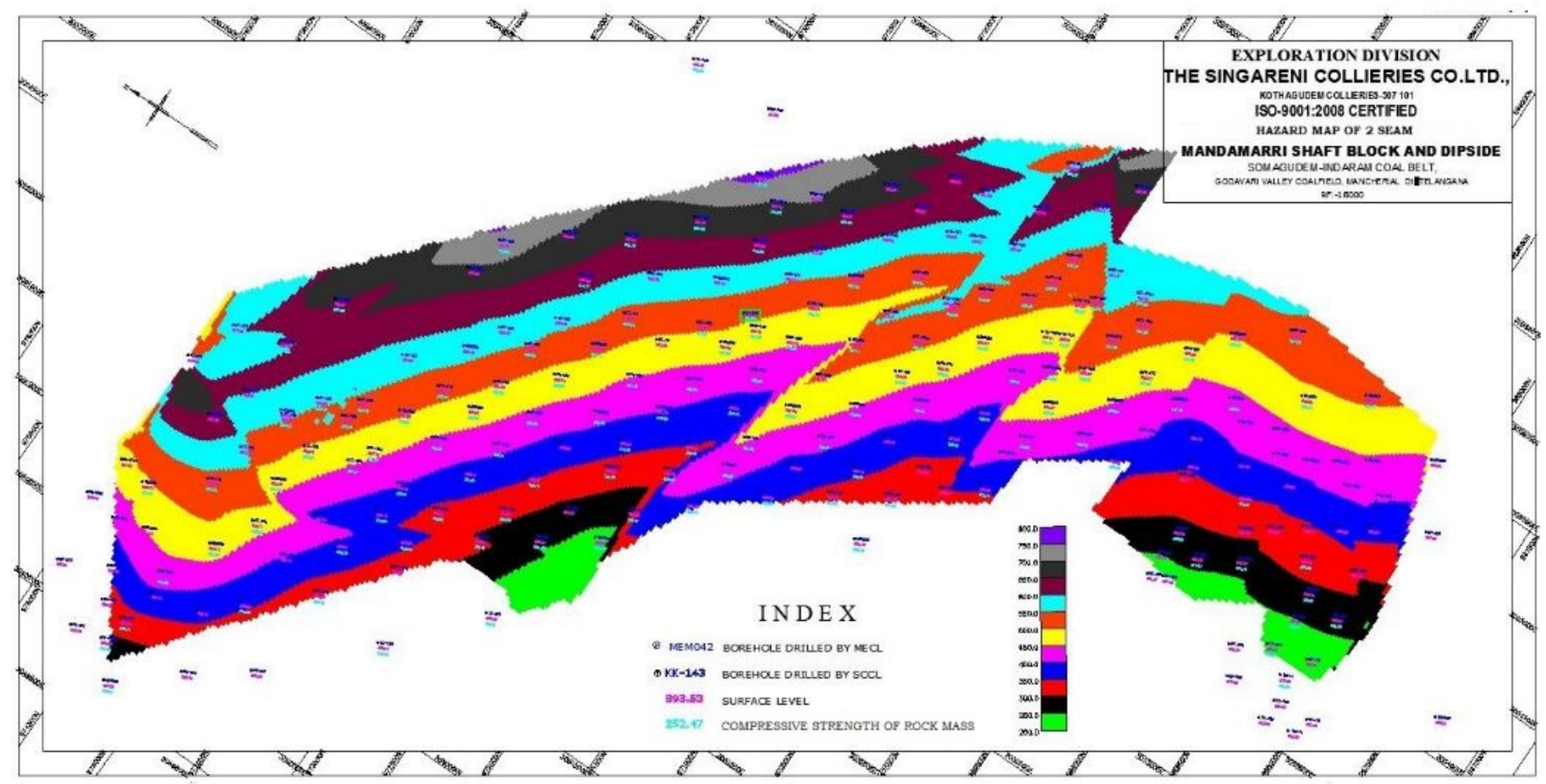

Figure 4

Hazard map of 2 seam (Compressive strength)

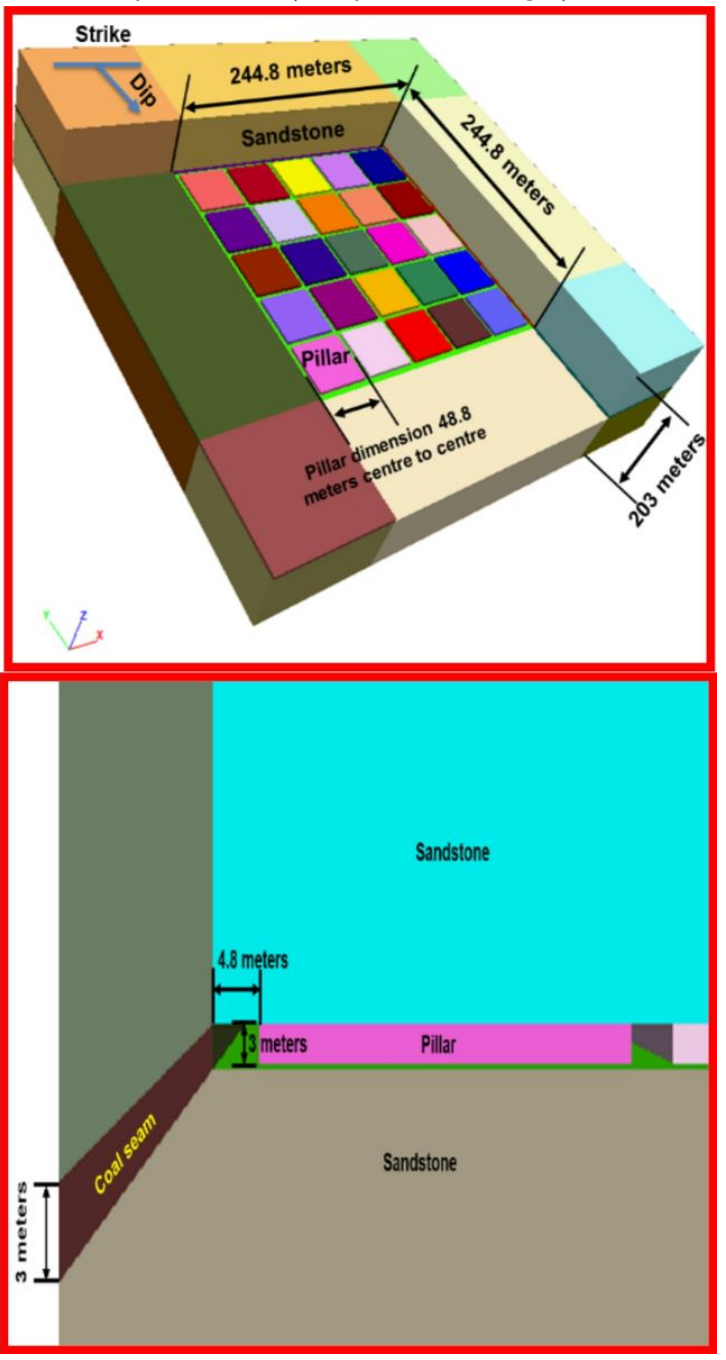


Figure 5

Layout of three-dimensional panel-wide model

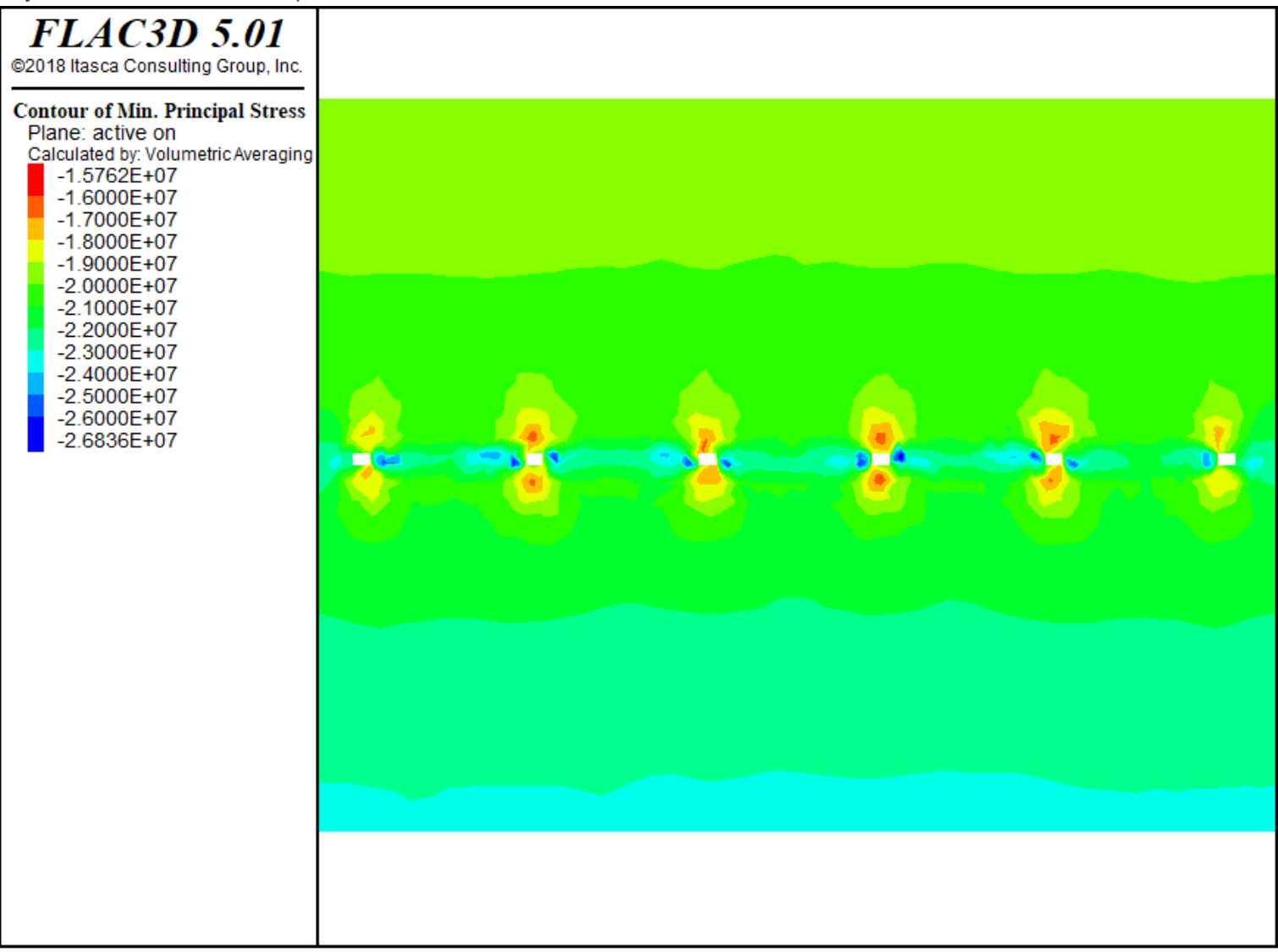

Figure 6

Contour plot of major principal stress SH parallel to level gallery

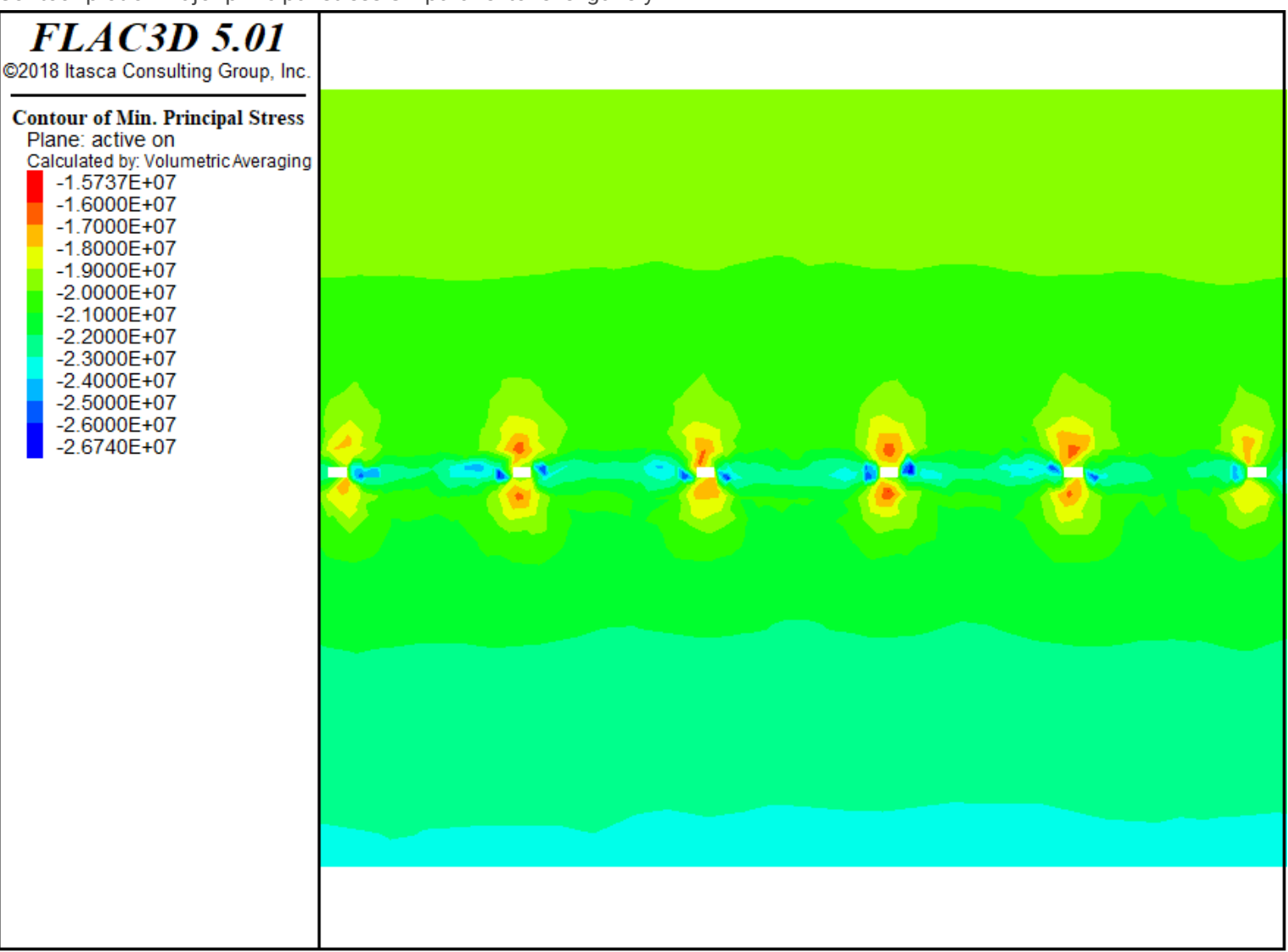


Contour plot of major principal stress $40 \otimes$ to the orientation of level gallery

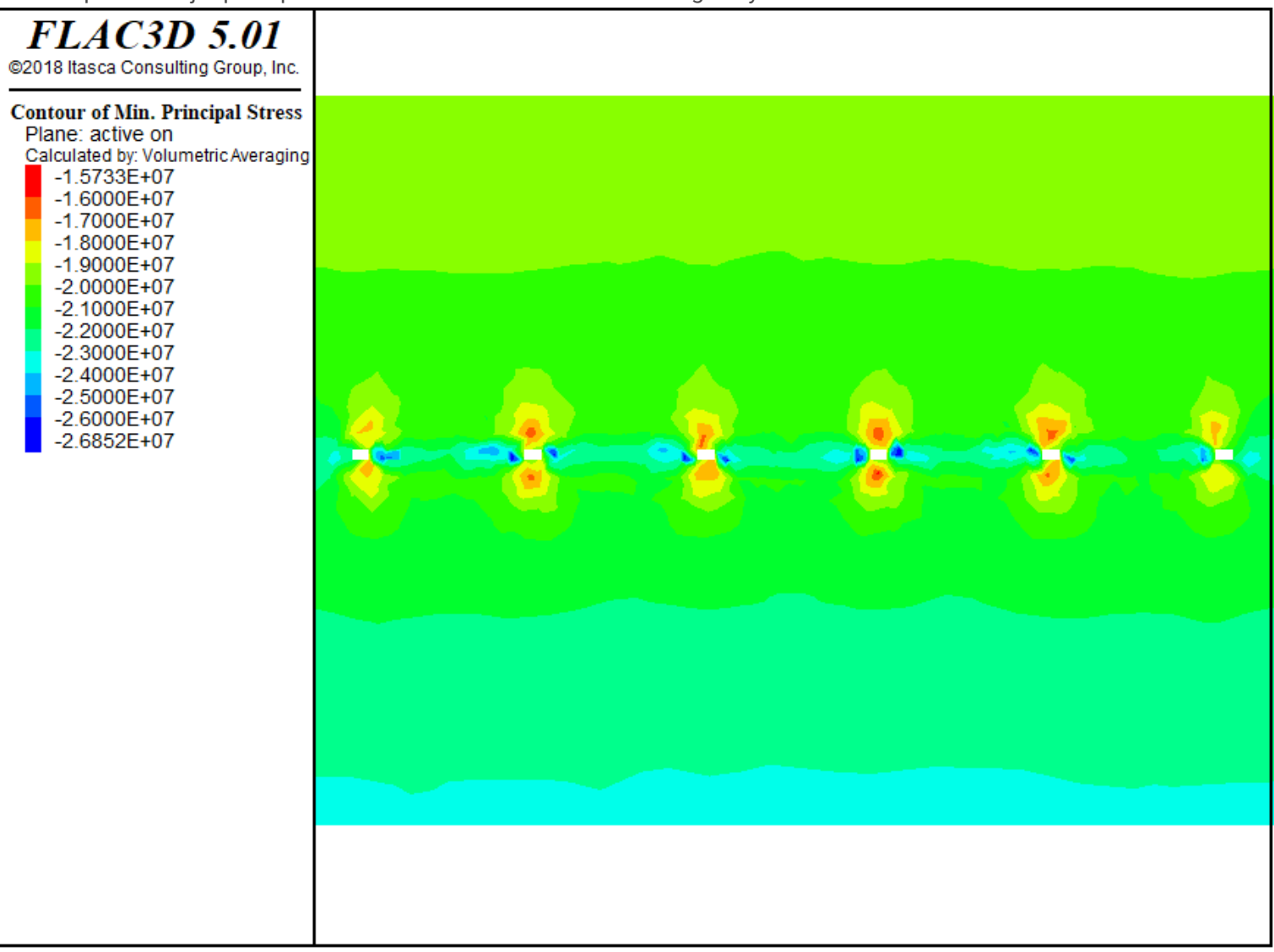

Figure 8

Contour plot of major principal stress perpendicular (85区) to the orientation of level gallery

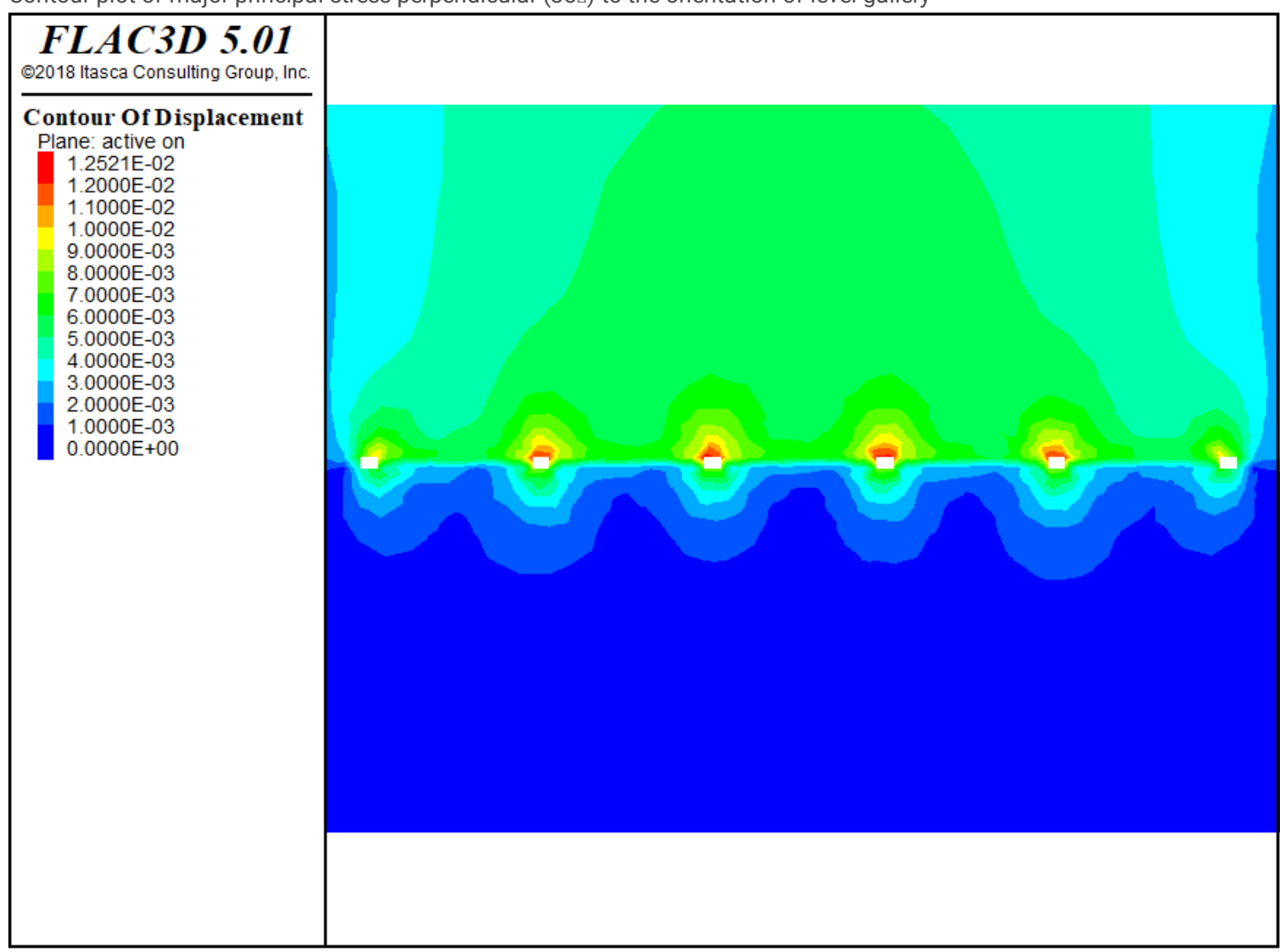


Figure 9

Contour plot of deformations SH parallel to level gallery

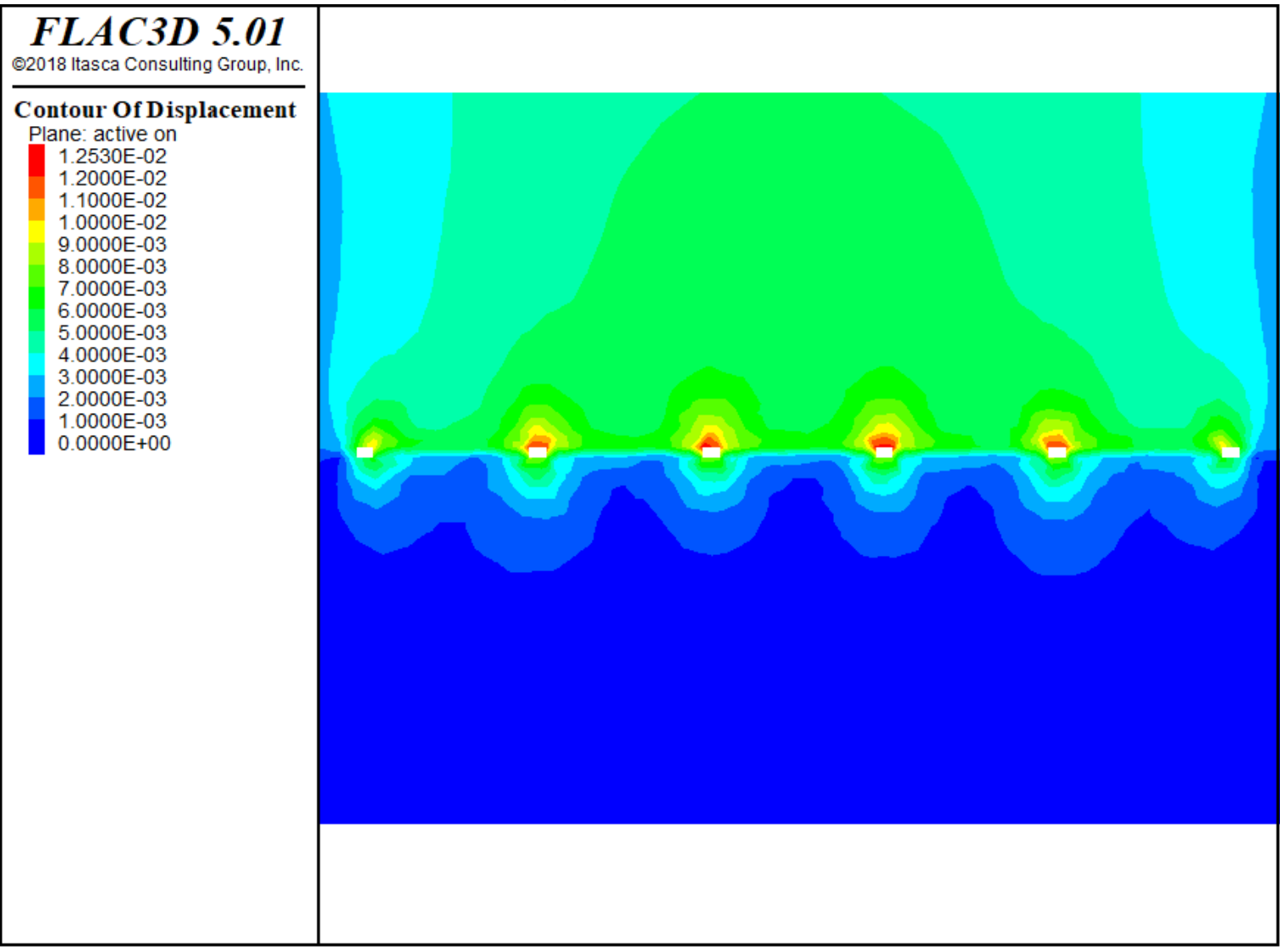

Figure 10

Contour plot of deformations $40 \otimes$ to the orientation of the level gallery

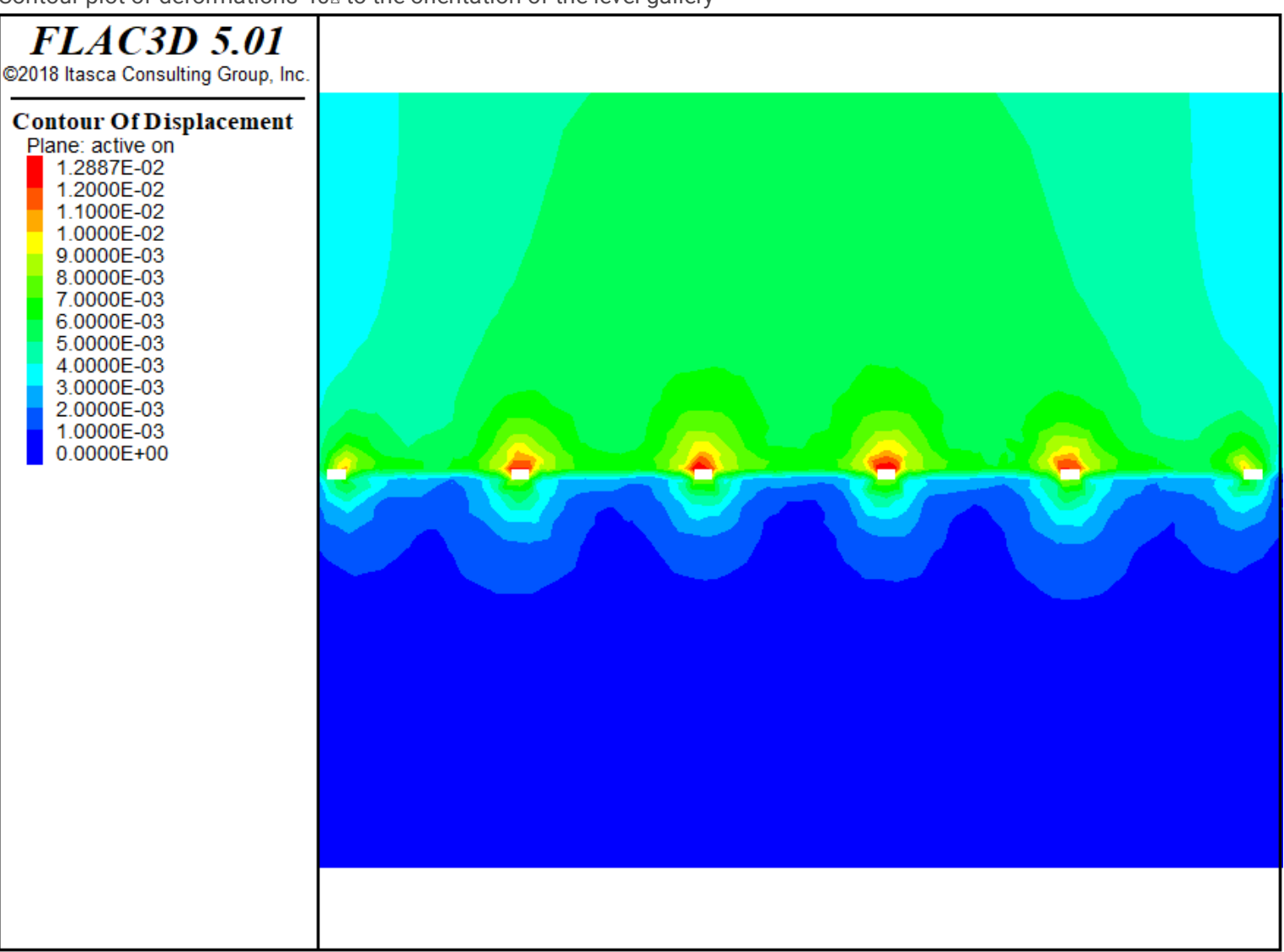

Page 10/15 
Figure 11

Contour plot of deformations perpendicular (85囚) to the orientation of the level gallery

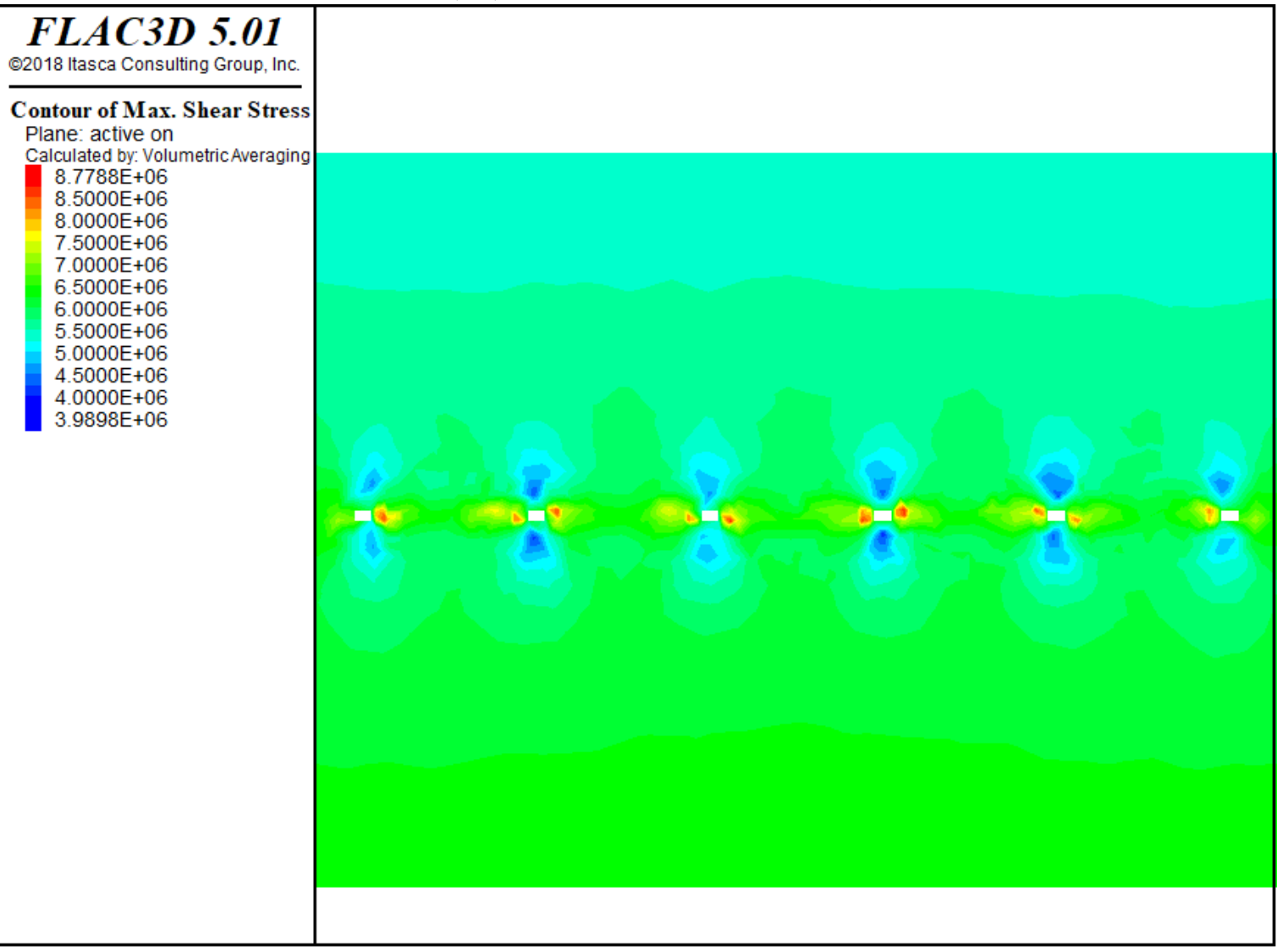

Figure 12

Contour plot of shear stress SH parallel to level gallery

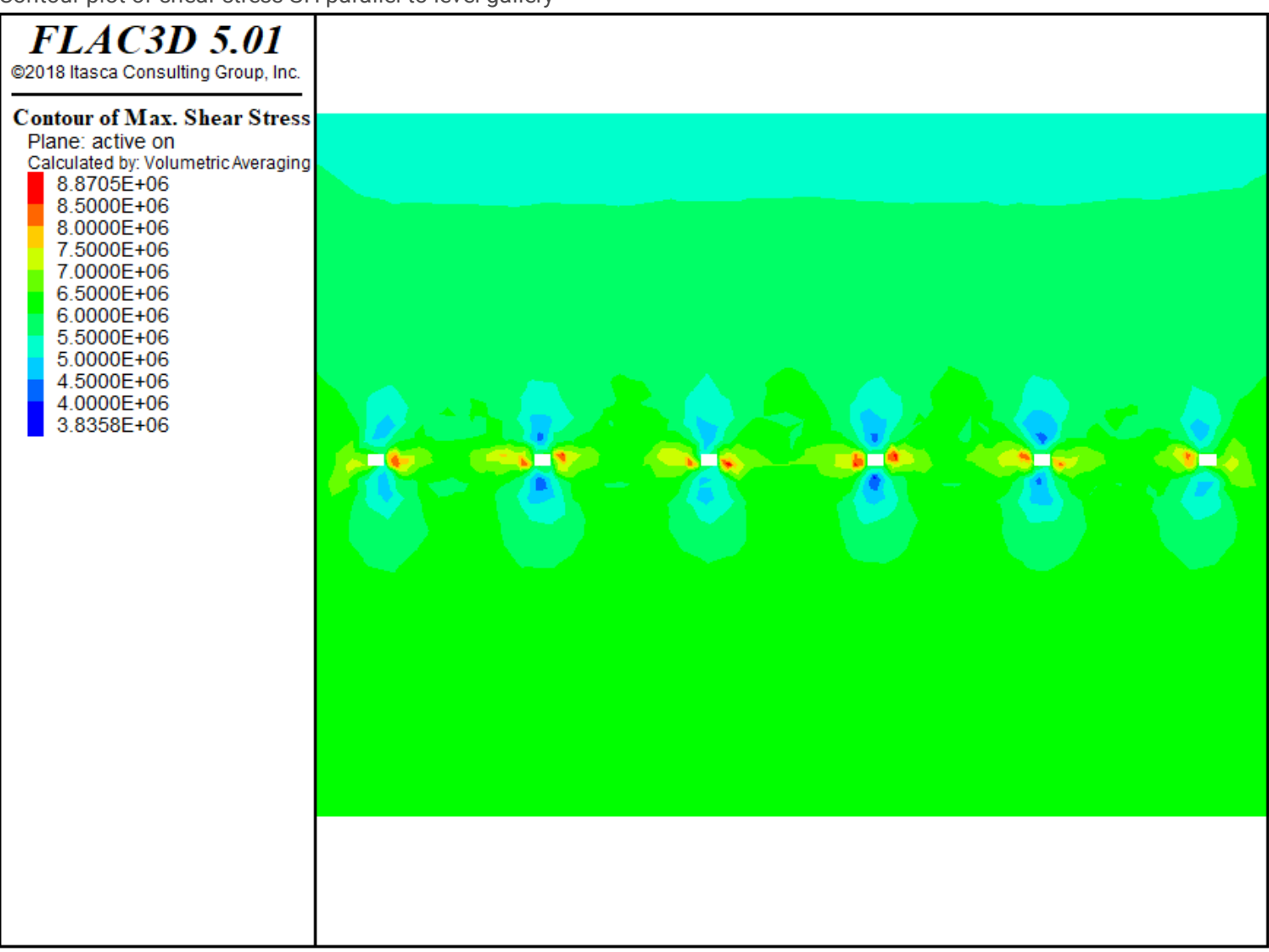

Page $11 / 15$ 
Contour plot of shear stress 408 to the orientation to level gallery

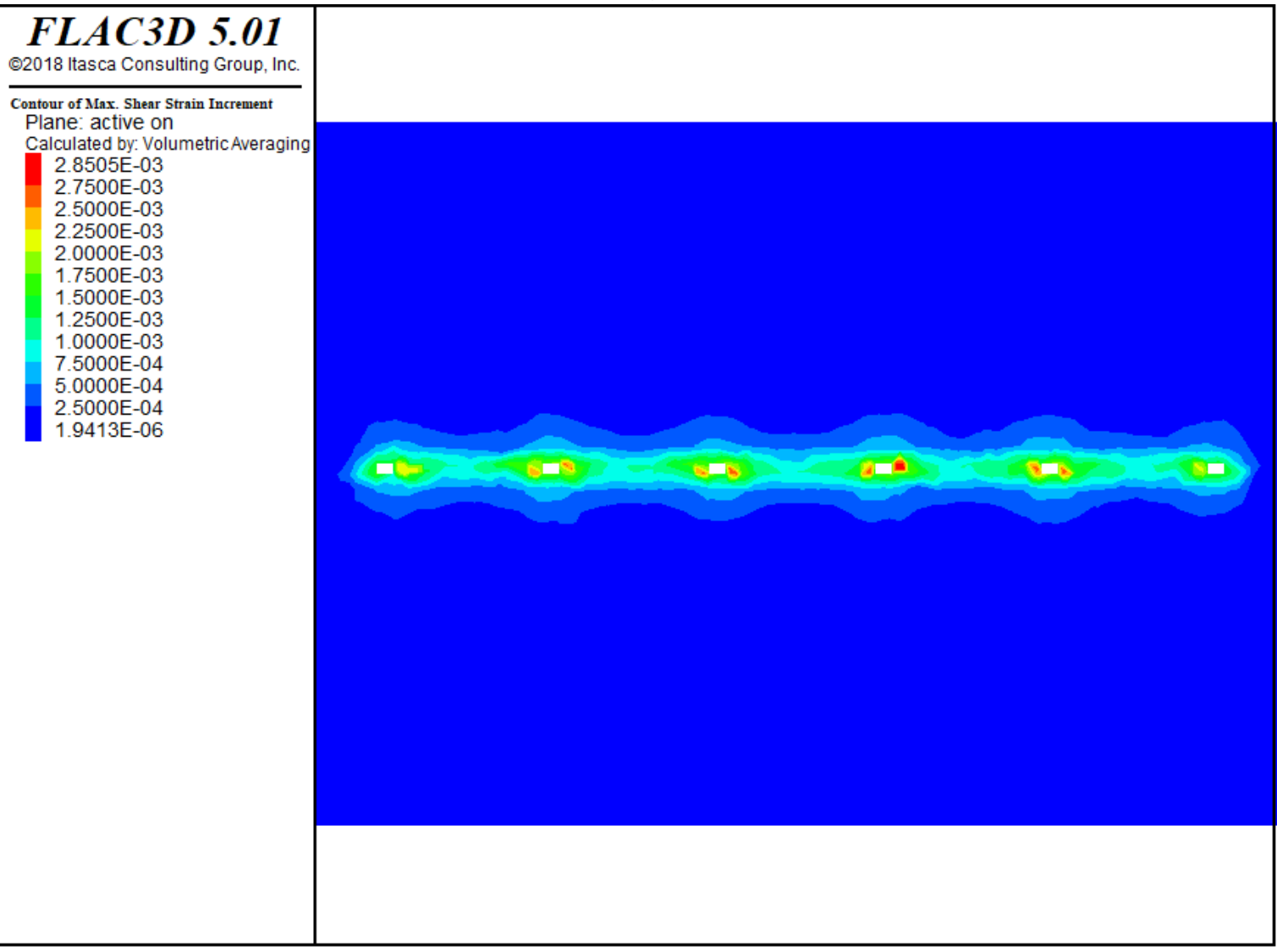

Figure 15

Contour plot of shear displacements SH parallel to level gallery

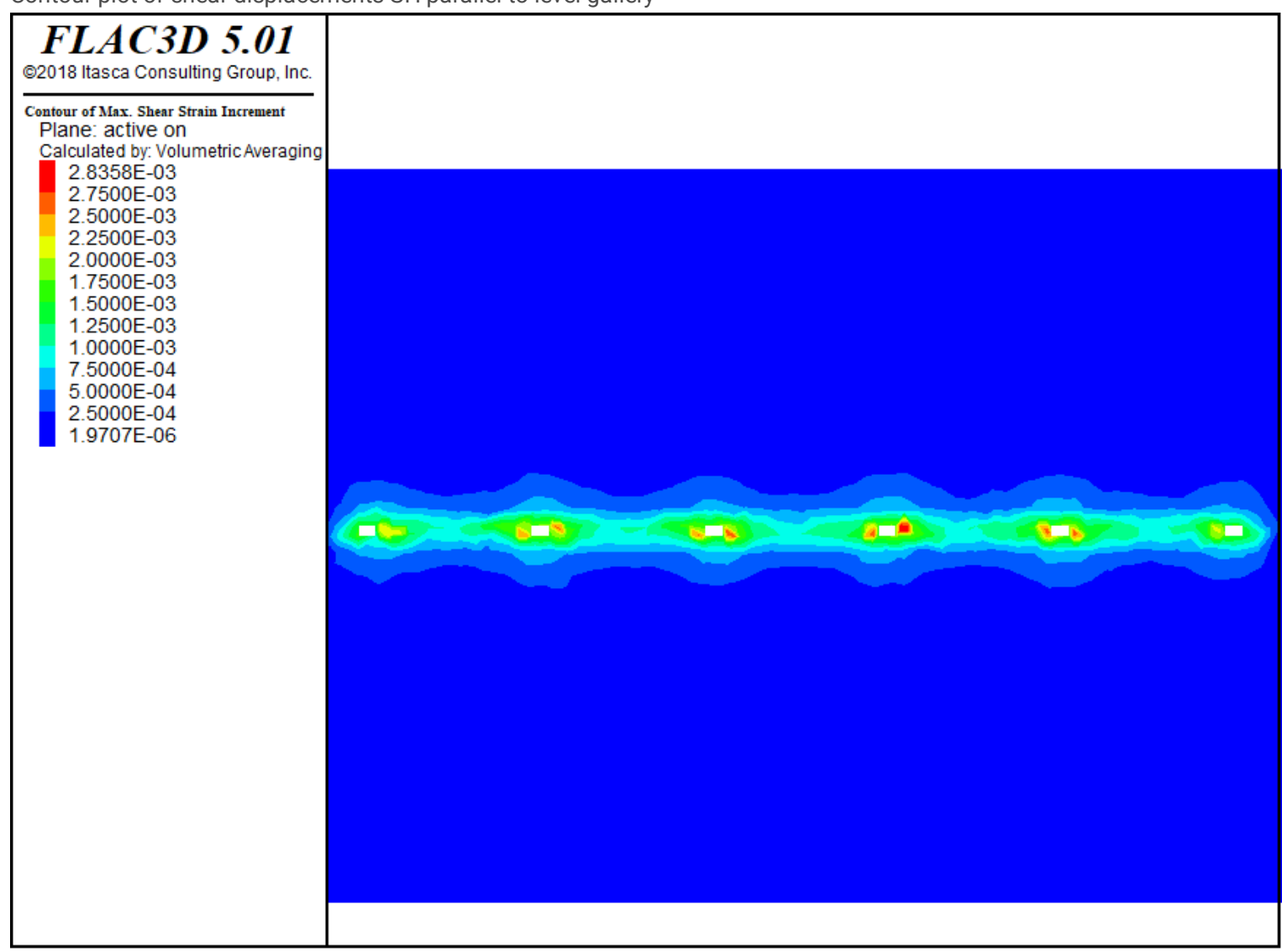


Figure 16

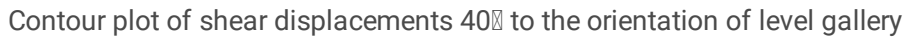

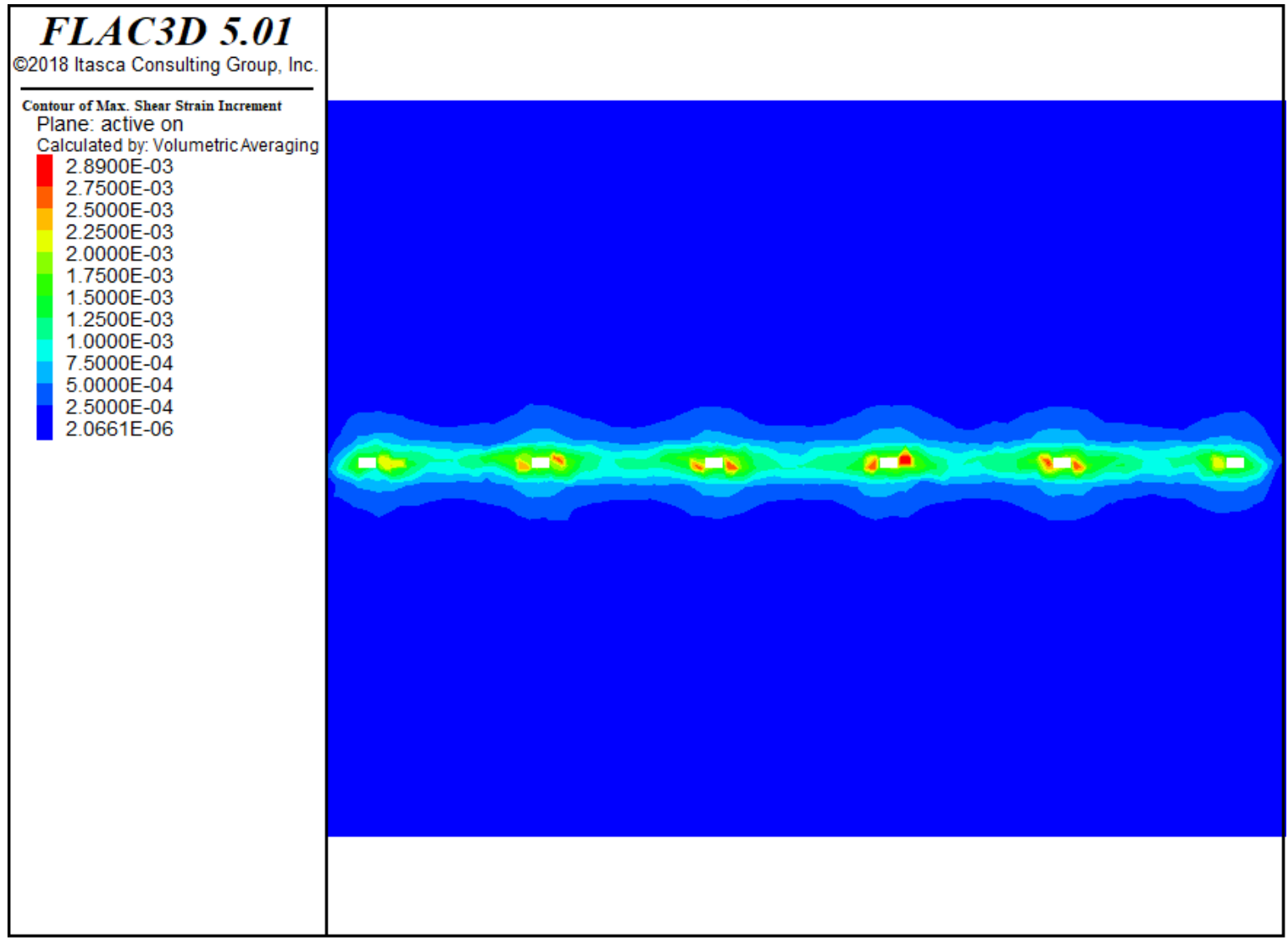

Figure 17

Contour plot of shear displacements perpendicular (85区) to the orientation of level gallery 

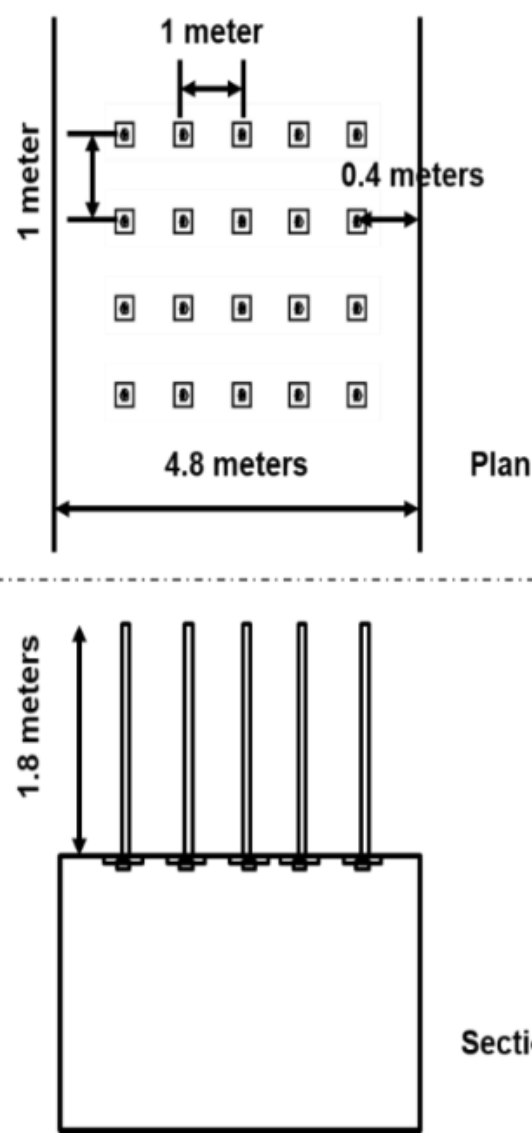

Section

Figure 18

Recommended support system for coal mine block 

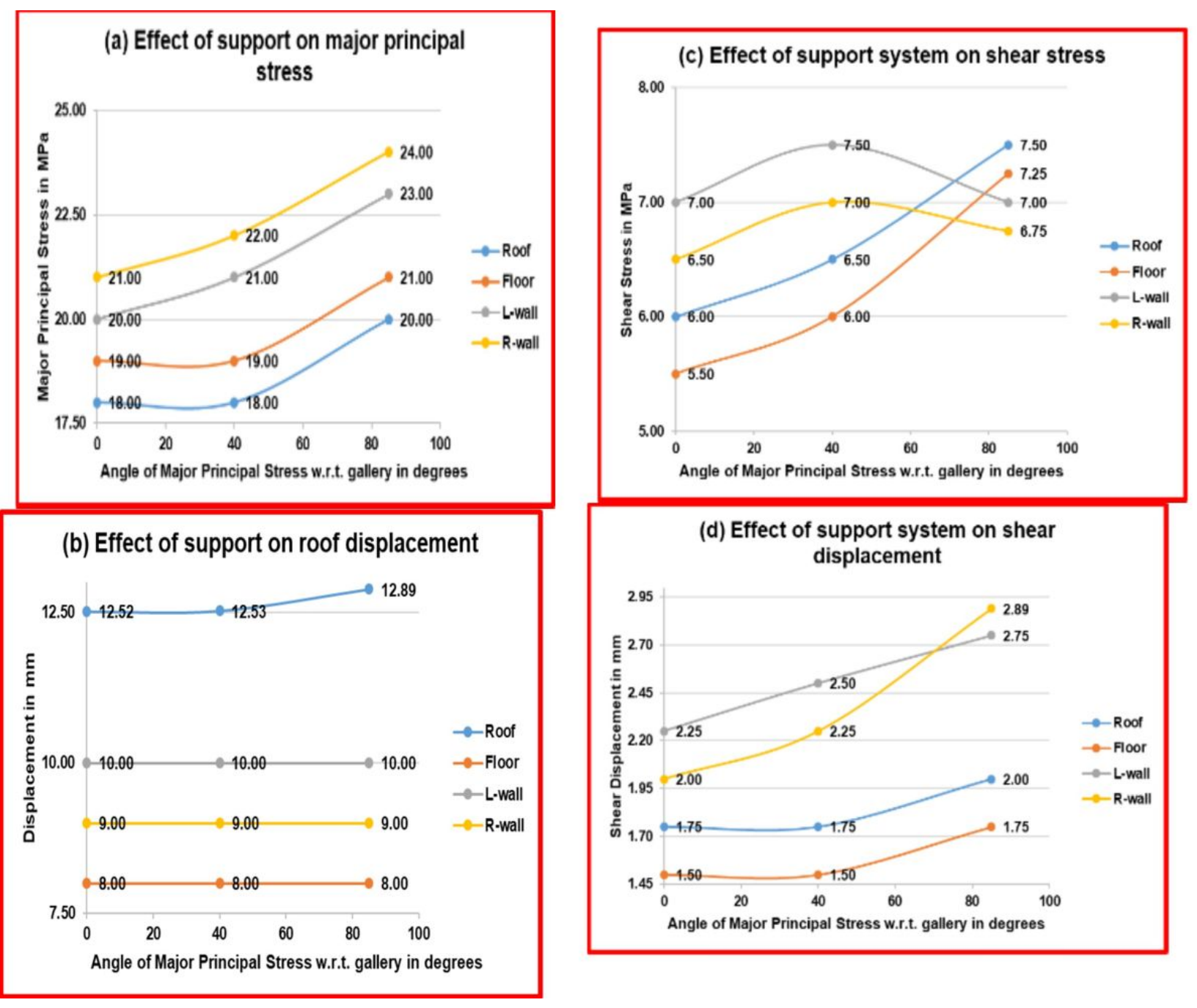

\section{Figure 19}

Effect of support on (a) major horizontal principal Stress, (b) Roof displacement, (c) Shear stress and (d) Shear displacement 